\title{
DIAPH3 Gene
}

National Cancer Institute

\section{Source}

National Cancer Institute. DIAPH3 Gene. NCI Thesaurus. Code C131337.

This gene plays a role in actin dynamics, Rho and Src localization, and cytokinesis. 